\title{
Heat Transfer Characteristics of Bulkhead Penetration Piece for A60 Class Compartment I: Transient Thermal
}

\author{
Woo-Chang Park", Chang Yong Song@ and Ok-Gyun Na** \\ *Department of Naval Architecture and Ocean Engineering, Mokpo National University, Jeonnam, Korea \\ *Hyundai-Samho Heavy Industry Co. Ltd., Jeonnam, Korea

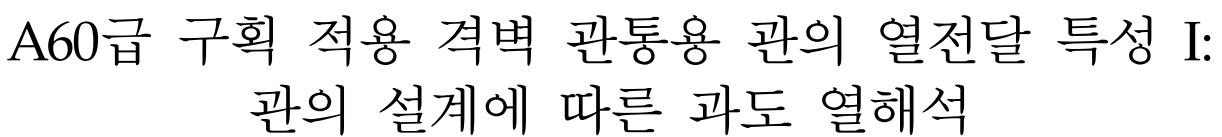 \\ 박우창 ${ }^{*}$ 송창용우 \\ *목포대학교 조선해양공학과 \\ *현대삼호중공업(주)
}

KEY WORDS: Ship and offshore plant fire accident 선박 및 해양플랜트 화재 사고, A60 class compartment A60급 구획, Bulkhead penetration piece 격벽 관통 관, Transient heat transfer analysis 과도 열전달 해석, Penetration piece design 관통관 설계

\begin{abstract}
In order to protect lives and prevent large-scale injuries in the event of a fire on a ship or an offshore plant, most classification societies are strengthening their fire resistance designs of relevant cargo holds and accommodation compartments to keep flames from being transferred from a fire point to other compartments. Particularly in critical compartments, where flames should not propagate for a certain period of time, such as the A60 class division, both the airtightness and fire-resistant design of a piece passing through a bulkhead are subject to the Safety of Life at Sea Convention (SOLAS) issued by the International Maritime Organization (IMO). In order to verify the suitability of a fire-resistant design for such a penetrating piece, the fire test procedure prescribed by the Maritime Safety Committee (MSC) must be carried out. However, a numerical simulation should first be conducted to minimize the time and cost of the fire resistance test. In this study, transient thermal analyses based on the finite element method were applied to investigate the heat transfer characteristics of a bulkhead penetration piece for the A60 class compartment. In order to determine a rational bulkhead penetration piece design, the transient heat transfer characteristics according to the variation of design parameters such as the diameter, length, and material were reviewed. The verification of the design specification based on a numerical analysis of the transient heat transfer performed in this study will be discussed in the following research paper for the actual fire protection test of the A60 class bulkhead penetration piece.
\end{abstract}

\section{1. 서 론}

선박이나 해양플랜트의 화재 발생 시 인명을 보호하고 대형 손상 사고로의 확대를 방지하기 위해 대부분의 선급에서는 화재 의 발화지점으로부터 다른 구획으로 화염이 전달되지 않도록 관 련된 화물창과 선실 등의 중요 구획에 대한 방화 설계 규정을 강화하고 있다. 특히 $\mathrm{A} 60$ 급 구획과 같이 일정시간 동안 화염이 전파되지 않아야 하는 중요한 구획에서는 격벽을 관통하여 연결 되는 관을 포함한 인접 부재의 기밀과 방화 설계를 국제 해사 기구(International Maritime Organization, IMO)에서 발행하는 해
상 안전 규정(Safety of Life at Sea Convention, SOLAS)에서 엄격 히 규제하고 있다. 이러한 $\mathrm{A} 60$ 급 격벽 관통 관에 대한 방화 설계 의 적합성을 검증하기 위해서는 해사안전위원회(Maritime Safety Committee, MSC)에서 규정한 화재시험절차(Fire test procedure, $\mathrm{FTP}$ )에 따라 시험을 수행해야 하지만, 방화 시험에 소요되는 시 간과 비용을 최소화하기 위해 열전달에 대한 수치해석적 검토가 선행될 필요가 있다. 선박 및 해양플랜트 분야에서 열해석과 관 련하여 여러 연구가 수행되어 오고 있다. Barletta et al.(2008)은 시동 작업 조건에서의 해양 매설 파이프에 대해 토양의 온도와 동일한 초기 온도에서 급격히 균일 온도에 도달하는 경우와 원

Received 14 July 2018, revised 14 October 2018, accepted 18 October 2018

Corresponding author Chang Yong Song: +82-61-450-2732, cysong@mokpo.ac.kr ORCID: http://orcid.org/0000-0002-1098-4205

(c) 2018, The Korean Society of Ocean Engineers

This is an open access article distributed under the terms of the creative commons attribution non-commercial license (http://creativecommons.org/licenses/by-nc/3.0) which permits unrestricted non-commercial use, distribution, and reproduction in any medium, provided the original work is properly cited. 
활하게 균일 온도에 도달하는 경우에 대한 과도 열전달 해석을 수행하였다. Huh et al.(2008)은 이산화탄소 해양지중저장 처리를 위한 파이프라인 수송시스템의 설계 중요 성능 인자인 압력강하 와 열전달 등을 설계 인자인 입구 $\mathrm{CO}_{2}$ 의 열역학적 상태, 유량, 수송 파이프라인 관경, 총괄 열전달 특성 등을 변화시켜가며 계산 을 수행하였으며 이를 통해 파이프라인 수송시스템의 설계기반을 제시하였다. 선박의 중연료유 탱크 내에 설치된 가온기의 최적설 계 관련하여 수조 실험과 열유동에 관한 CFD(Computational fluid dynamics) 시뮬레이션 수행을 통해 열유동을 고려한 구조물 설 계시 시률레이션 기반 성능평가가 유효함을 확인하는 연구가 수 행되었으며(Moon et al., 2010), 빙해선박 상부갑판 열선에 대하 여 다양한 실외 온도 및 풍량에서 열선의 열전달 능력 및 배치 간격을 통해 최적의 착빙방지 설계 기준을 제시하는 연구가 수 행되었다(Lee et al., 2012). Zhou et al.(2017)은 화염 절단을 사용 한 선체의 절단 개구 생성과 관련된 열역학적 거동을 분석하기 위해 열전달 수치 시뮬레이션을 수행하였다. Kang et al.(2017)은 LNG(Liquefied natural gas) 운반선 탱크의 극저온 폭발 방지 카 메라의 설계 및 열전달 해석을 수행하였으며 실제 극저온 시험 결과와 비교 검토하였고 예열 시간 및 작업 시간을 검토하였다. 선박엔진 배관 플랜지용 세미금속 가스켓의 구조 건전성을 평가 하기 위해 플랜지 내부의 유체 최대온도 및 최대 압력 조건에서 열전달 및 구조해석 수행을 통해 기존의 가스켓 대비 제작비용 과 경제성 측면에서 유리함이 확인되었다(Oh et al., 2017). Murawski(2018)는 3,000TEU 컨테이너선에 장착된 저속 엔진을 대상으로 메인 엔진에서 발생하는 열에 의한 추진 시스템 샤프 트 라인과 크랭크축의 변위 해석을 수행하였다. 기존의 연구문 헌을 살펴본 바와 같이 국 - 내외 연구 사례 중에서 선박 및 해 양플랜트용 $\mathrm{A} 60$ 급 관통 관에 대한 열전달 수치해석 분야에 대 한 연구의 수행 사례가 미비함을 확인할 수 있다.

본 연구에서는 $\mathrm{A} 60$ 급 구획에 적용되며 격벽을 관통하는 관의 열전달 특성을 검토하기 위해 유한요소법을 기반으로 한 과도 열전달 수치해석 기법을 적용하였다. 과도 열전달 수치해석은 범용 유한요소해석 프로그램인 MSC.NASTRAN의 열해석 솔버 를 사용하였으며, MSC.307(88)에서 규정하고 있는 A60급 격벽 관통 관의 방화성능 검증을 위한 화재시험절차와 동일한 시편 사양, 온도조건 및 가열시간을 고려하여 수치해석 모델과 해석 조건을 구성하고 열전달 수치 시뮬레이션을 수행하였다. 또한 선박 및 해양플랜트 건조에 실제적으로 적용 가능한 A60급 격 벽 관통 관의 합리적인 설계를 결정하기 위해 다양한 설계 파 라미터 변경에 따른 과도 열전달 특성을 검토 하였다. 본 연구 에서 선정한 격벽 관통 관의 설계 파라미터로는 관의 재질, 직 경 및 길이 치수이며, $\mathrm{A} 60$ 급 방화성능의 온도 규정, 제작비용 및 건조 생산성 등을 주요 성능 응답치로 고려하여 합리적인 $\mathrm{A} 60$ 급 격벽 관통 관의 설계 사양을 검토하였다. 설계 파라미터 검토 결과로부터 길이보다 재질, 직경 및 관 형상의 설계조합이 방화성능에 영향도가 높은 것을 확인하였다. 또한 제작비용과 관련하여 황동, SUS316L, S45C의 소재 적용 순서로 제작비용이 낮아짐을 확인하였고, 생산성 측면에서는 황동재질을 적용하고 직경이 크고 길이가 짧은 경우 생산성이 향상되는 것으로 나타 났다. MSC.307(88) 방화성능의 온도규정 만족여부와 관련하여 $\mathrm{S} 45 \mathrm{C}$ 재질의 경우 직경 및 길이에 관계없이 온도규정을 만족하
지 못하였으며, 재질이 황동일 때 튜브의 직경이 $\phi 12$ 인 경우 길이에 관계없이 온도규정을 만족하지 못하였다. 반면 재질이 $\mathrm{SUS} 316 \mathrm{~L}$ 인 경우 직경 및 길이에 관계없이 모두 온도규정을 만 족하였다. 이와 같은 연구결과를 통해 MSC.307(88) 방화성능의 온도 규정, 제작비용 및 건조 생산성을 종합적으로 고려하여 $\mathrm{A} 60$ 급 격벽 관통 관의 가장 합리적인 설계 사양을 결정하였다. 본 연구에서 수행된 수치해석 기반의 설계 사양 결정에 대한 검증은 추후 방화성능 시험 연구논문에서 다루어질 예정이다.

\section{2. $\mathrm{A} 60$ 급 격벽 관통 관의 설계}

선박 및 해양플랜트에 사용되는 격벽 관통 관(Bulkhead penetration piece)은 격벽의 기밀성을 유지함과 동시에 선내외에 포설되는 각종 제어, 모니터링 및 통신용 케이블의 안전한 설치 와 운용을 위해 사용된다. Fig. 1에 나타난 바와 같이 격벽 관통 관의 내부를 통해서 케이블 등이 설치되고, 격벽 관통 관이 적 용되는 구획의 화재 등급에 따라 관의 재질(Steel, Copper, Al-alloy, PVC)과 단열재 사용 여부가 결정된다(ABS, 2018). Fig. 1 에서 $\mathrm{A} 0, \mathrm{~A} 15, \mathrm{~A} 30, \mathrm{~A} 60$ 등급은 각각 0 분, 15,30 분, 60 분 동안 규정된 화재온도 변화에 대해 방화성능을 유지해야 하는 것을 나타낸다.

본 연구에서 고려한 $\mathrm{A} 60$ 급 격벽 관통 관의 설계와 관련되어 각 선급뿐만 아니라 SOLAS에서도 MSC.307(88)에 규정된 FTP 코드에 따라 방화시험을 수행하여 방화설계 사항을 검증하거나, 단열재를 포함하여 $3 \mathrm{~mm}$ 이상의 두께와 $900 \mathrm{~mm}$ 이상의 길이를 갖는 강재 혹은 등가의 재질로 관통 관을 설계 및 시공하도록 규정하고 있다(IMO, 2010; MSC, 2010). 그러나 국내의 거의 모 든 조선소에서는 $\mathrm{A} 60$ 급 격벽 관통 관의 설계와 시공에 대해 FTP 코드에 따른 방화시험을 통해 검증된 방화설계를 적용하지 못하였음에도 불구하고 $900 \mathrm{~mm}$ 이상의 길이에 대한 규정도 준 수하지 못하고 있다. 이러한 문제점은 $\mathrm{A} 60$ 급 격벽 관통 관의 형 상적인 특징과 생산 공정상의 작업 난이도로 인해 발생하는데, 격벽 관통 관의 길이가 길어지면 시공 시 구조적인 변형문제, 관 내부로의 케이블 관입 작업 생산성 저하 등의 문제가 발생 한다. Fig. 2에는 국내 대형 조선소에서 일반적으로 적용되고 있 는 $\mathrm{A} 60$ 급 격벽 관통 관의 표준 설계형상의 예가 나타나 있다.

Fig. 2에 나타난 바와 같이 외경이 $\phi 12$ 미만인 내부 튜브 (Tube)가 외경 $\phi 25$ 미만인 소켓(Socket, (1), 바이트(Bite, (2) 및 너트(Nut, (3)로 구성된 조립체에 연결되는 형태로 A60급 격벽 관통 관이 구성되고, 격벽 관통 관의 설치 영역이 탱크 상부 (Tank top) 및 보이드 스페이스(Void space) 혹은 풍우밀(Weather tight) 인지에 따라 관통 관 형태의 차이가 발생한다. 선급이나 $\mathrm{MSC}$ 에서 규정하고 있는 $900 \mathrm{~mm}$ 이상의 관 길이를 적용할 경우 과도한 관의 길이로 인해 통과하는 케이블의 설치나 유지보수 시에 관의 변형이나 케이블의 절손이 자주 발생하고 시공 작업 성이 나빠지게 된다. 이러한 이유로 관의 길이를 최소화하고 이 에 대한 방화설계 규정의 만족 여부를 검증하는 것이 필요하다. $\mathrm{A} 60$ 급 격벽 관통 관의 방화성능 검증은 FTP 코드에서 규정하 고 있는 시편 설계와 화재시험절차를 준수해야 한다. Fig. 3에는 FTP 코드에 규정된 A60급 격벽 관통 관의 방화성능 검증용 시 편의 형상이 나타나 있다. 

(1) "A-0" Class
(2) "A-15", "A-30", "A-60" Class
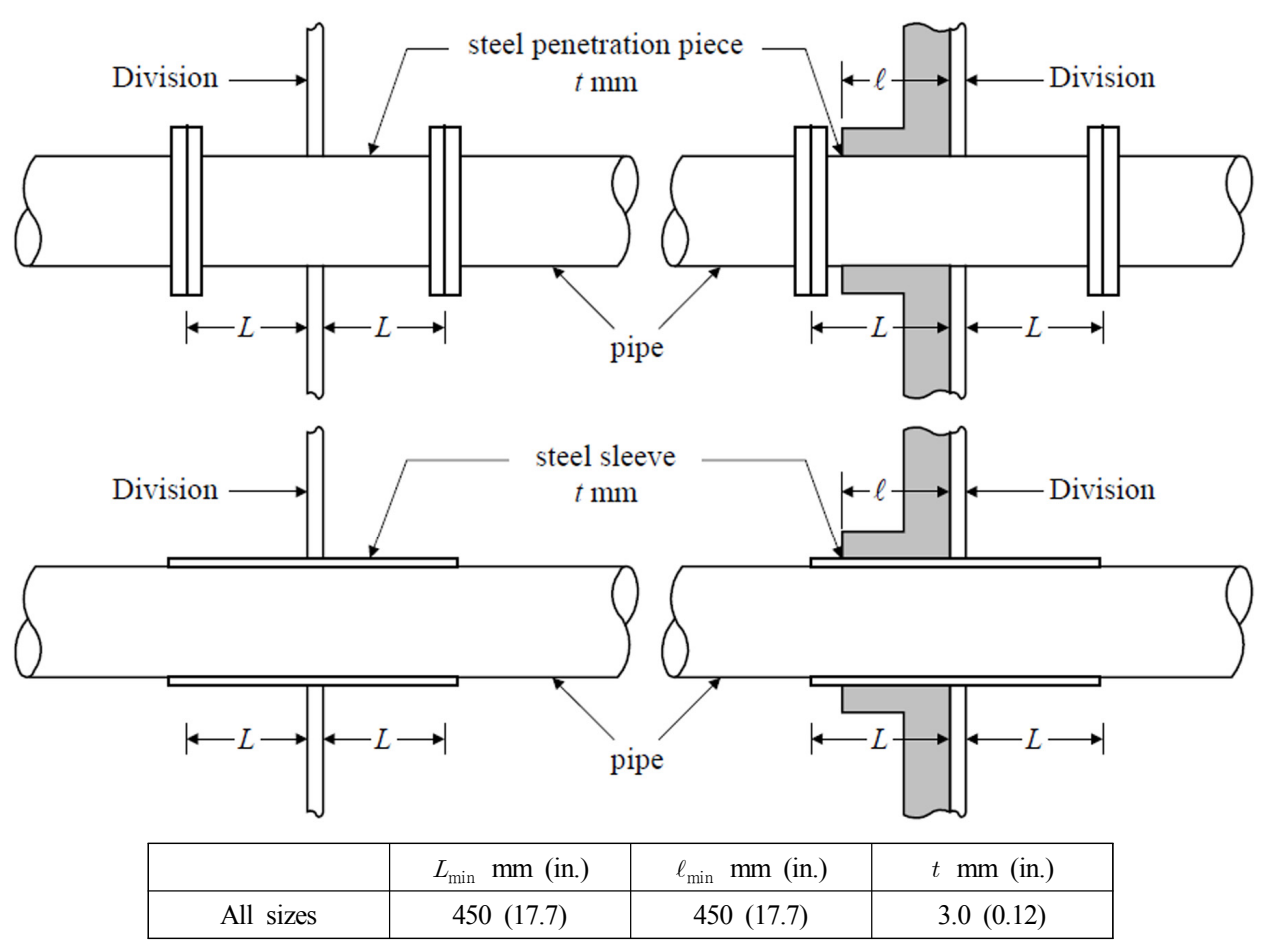

Fig. 1 Bulkhead penetration piece for "A" class divisions (ABS, 2018)

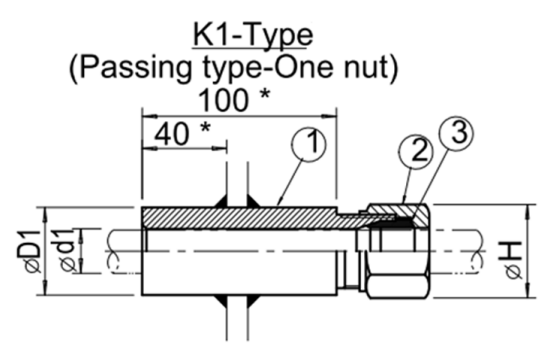

To be applied on tank top \& In void space

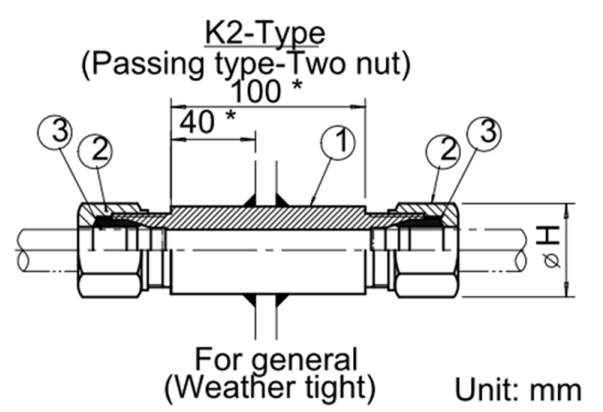

(Weather tight) Unit: $\mathrm{mm}$

(a) standard design drawing

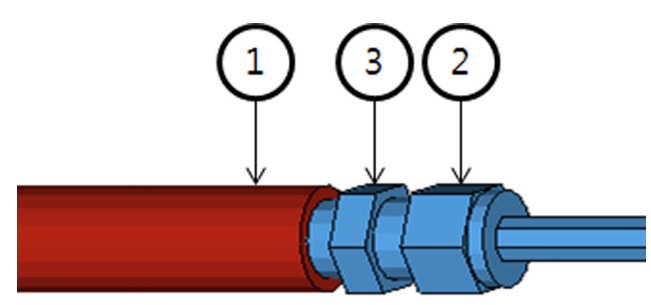

(b) 3-D concept model

Fig. 2 A60 class bulkhead penetration piece design

Fig. 3 과 같은 시편의 수직 보강재 사이에 시험하고자 하는 격벽 관통 관을 설치한 후 시편의 한쪽 면을 60 분간 약 $940^{\circ} \mathrm{C}$ 의 온도로 상승시킬 수 있는 화염노(furnace)에 장착하여 방화시험 을 수행하게 된다. 적합한 $\mathrm{A} 60$ 급 격벽 관통 관의 방화성능은 60 분의 화염시험 동안 시편에 화염이 가해지는 반대쪽 면의 온도 가 상온 $20^{\circ} \mathrm{C}$ 를 기준으로 $180^{\circ} \mathrm{C}$ 미만의 편차로 유지되도록 규 정되어 있다(MSC, 2010). 본 연구에서는 실제 방화성능 시험을
수행하기에 앞서 Fig. 3과 같이 FTP 코드에 규정된 A60급 격벽 관통 관의 방화성능 검증용 시편과 Fig. 2에 나타나 있는 격벽 관통 관을 유한요소모델로 생성하고 시험조건과 동일한 가열조 건을 적용하여 유한요소법 기반의 과도 열전달해석을 수행한다. 이러한 과도 열전달해석을 통해 FTP 코드에 규정된 방화성능을 만족할 수 있는 격벽 관통 관의 길이, 직경 및 재질의 설계 조 합을 탐색하는 것이 본 연구의 주요 목적이다. 

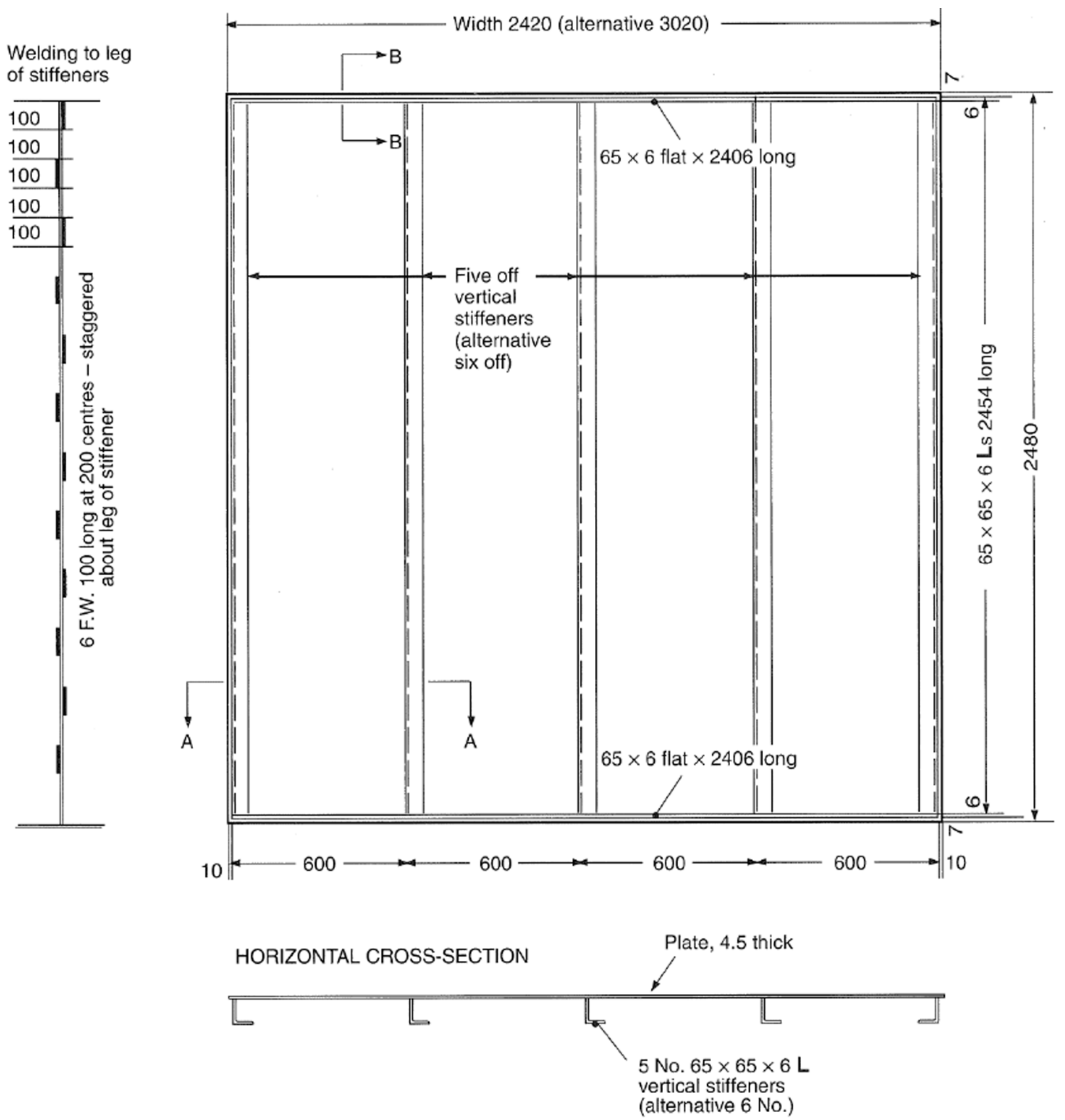

(a) structure steel core design drawing

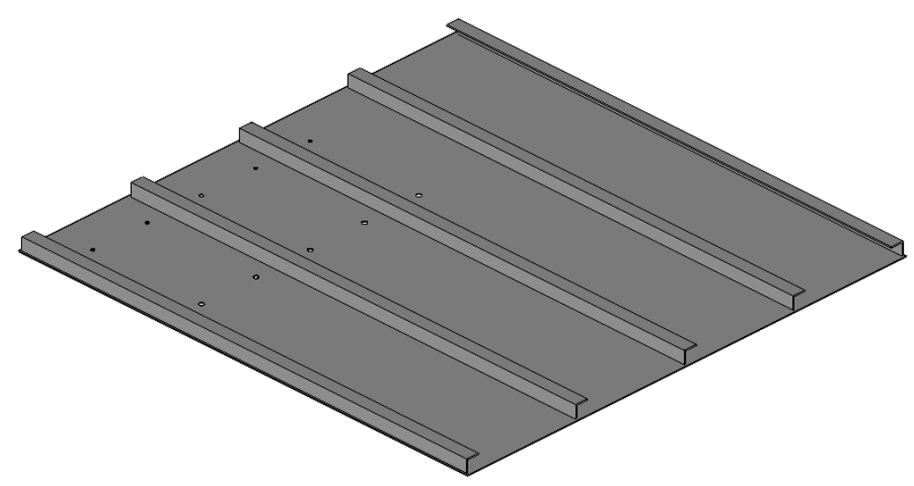

(b) 3-D concept model

Fig. 3 Structure steel core for "A" class bulkhead (MSC, 2010) [unit:mm] 


\section{3. 과도 열전달 수치해석}

\section{1 과도 열대류 이론}

과도 열전달(Transient heat transfer) 문제는 온도가 위치뿐만 아 니라 시간에 따라서도 변화하므로 비정상 문제의 수치해법에서 공간의 이산화와 함께 시간의 이산화도 필요하게 되며, 시간 간격 $\Delta t$ 를 설정하여 요구되어지는 시간에서 해가 얻어질 때까지 각 $\Delta t$ 에서 미지의 절점 온도에 대한 반복 해를 구하는 방법이 적용된다. 열전달 현상 중 대류(Convection)는 고체면과 유동하는 인접한 유 체 사이에서 발생하는 열전달이며 전도(Conduction)와 유체운동 (Fluid motion)이 복합적으로 영향을 준다. 대류 열전달은 유체속도 $v$, 유체의 물성치인 동점성계수 $\mu$, 열전도도 $k$, 밀도 $\rho$, 비열 $C_{p}$ 에 의하여 좌우된다. 또한 형상과 고체 표면의 거칠기, 그리고 유체 유동의 형태에도 관계가 있다. 대류열전달률은 온도차에 비례하 며, 다음과 같이 Newton의 냉각법칙(Newton's law of cooling)으로 표시된다(Yunus and Afshin, 2012).

$$
\begin{aligned}
& \dot{q}_{\text {conv }}=h\left(T_{s}-T_{\infty}\right) \\
& \dot{Q}_{\text {conv }}=h A_{s}\left(T_{s}-T_{\infty}\right)
\end{aligned}
$$

여기서 $A_{s}$ 는 대류열전달이 발생하는 면적, $T_{s}$ 는 물체 표면 온 도, $T_{\infty}$ 는 표면에서 충분히 멀리 떨어진 곳에서 유체의 온도이 다, $h$ 는 대류열전달계수로서 다음과 같은 식으로 표현된다.

$$
h=\frac{-k_{\text {fluid }}(\partial T / \partial y)_{y=0}}{T_{s}-T_{\infty}}
$$

여기서 $k_{f l u i d}$ 는 유체의 열전도도이다. 식 (3)으로부터 온도분포 를 산출하기 위해서 대류열전달계수의 추정이 필요하며, 누셀 트 수(Nusselt number)와 단위 시간동안의 단위 표면적에 대한 열전달율인 열플럭스의 관계식을 이용하여 추정할 수 있다. 누 셀트 수는 레이놀드 수(Reynolds number)와 프란틀 수(Prandtl number)의 관계식으로부터 산출될 수 있는데, 레이놀드 수와 프 란틀 수는 유체의 상류속도, 기하학적 특성길이, 유체 동점성 계수 및 재료 열 확산율로부터 산출된다. $\mathrm{A} 60$ 급 격벽 관통 관의 방화성능시험은 $\mathrm{MSC}$ 에서 규정된 화염노에서 60 분간 $940^{\circ} \mathrm{C}$ 의 분위기 온도(Atmospherical temperature)를 시편에 적용하는 방식 이기 때문에 화염노 내부의 공기 특성치와 시험시편의 형상을 고려하여 대류열전달계수를 산정하여 수치해석에 사용하였다.

\section{2 과도 열전달 수치해석모델 및 설계 파라미터 설정}

$\mathrm{MSC}$ 의 FTP 코드 상에 규정된 시편 규격에 따라 시편설계가 수행되었으며, 본 연구에서 사용된 격벽 관통관의 배치와 단열 재의 구성 및 상세 사양은 Fig. 4 및 Table 1에 나타내었다.

Table 1에 나타나 있는 바와 같이 격벽 관통 관의 직경 및 재 질에 대한 설계 파라미터의 설정과 관련하여 실제 조선소에서 적용 가능한 설계 사양의 조사를 통해 튜브의 직경은 $\phi 8$ 와 $\phi$ 12 , 소켓의 직경은 $\phi 18$ 와 $\phi 25$, 재질은 SUS316L, S45C, 황동 (Brass)의 3 가지 재질로 고려하였다. $1 \sim 5$ 번의 격벽 관통 관은 $\phi$
8 튜브와 $\phi 18$ 소켓의 조립체로 구성하였고, 6 10번의 격벽 관 통관은 $\phi 12$ 튜브와 $\phi 25$ 소켓의 조립체로 구성하였다. 튜브 재 질이 황동인 경우 용접성 등의 이유로 소켓 재질을 $\mathrm{S} 45 \mathrm{C}$ 로 설 정하였으며, 이외의 격벽 관통 관은 튜브와 소켓의 재질을 동일 하게 설정하였다. 격벽 관통 관은 사용 용도에 따라 튜브가 소 켓 내부에서 단절된 절단형(Cutting type)과 튜브가 소켓 내부를 연속적으로 통과하는 관통형(Passing type)으로 설계된다. 이를 고려하기 위해 Fig. 4에 나타나 있는 바와 같이 1 3번, 6 8번 격 벽 관통 관은 절단형으로 고려하였으며 4,5 번 및 9,10 번 격벽 관통 관은 관통형으로 고려하였다.

시공 작업성에 큰 영향을 미치는 격벽 관통관의 길이 영향도 를 고려하기 위해 Fig. 5와 같이 소켓의 길이를 $200 \mathrm{~mm}, 350 \mathrm{~mm}$, $500 \mathrm{~mm}$ 의 3 가지 파라미터로 설정하였고, 이때 화염 비노출면 (Unexposed)의 동일위치에서의 온도 분포를 비교하기 위해 화염 노출면(Exposed) 방향으로 소켓 길이를 확장하여 고려하였다.

격벽 관통 관을 설치하기 위한 시편의 사양은 Fig. 4 및 Table 1 에서와 같이 A E에 나타나 있으며, 주요치수 및 재질은 MSC 의 FTP 규정을 준수하여 적용되었다. 시편 단열재의 제품명은 Spray S이고 밀도 $140 \mathrm{~kg} / \mathrm{m}^{3}$ 의 도포 형식 단열재를 적용하였으 며, A60 격벽 방화시험 규정에 따라 화염 비노출면에 도포되는 것으로 고려하였다. $\mathrm{A} 60$ 급 격벽 관통 관의 방화성능 검토를 위 한 과도 열전달해석의 수행과 연계된 설계 파라미터 설정사항 은 Table 2와 같이 정리하여 나타내었다.

Table 2에 나타난 바와 같이 실제 조선소에서 적용 가능한 튜 브와 소켓의 치수와 재질, 그리고 격벽 관통 관의 형태를 10 개 의 Case로 구성하고, 각 Case 별로 소켓 길이를 3 가지 형태로 적용하였다. 과도 열전달해석은 Table 2 에 따라 총 30 가지 해석 모델에 대해 수치해석을 수행하고, 수치해석 결과를 기반으로 각 설계 파라미터에 대한 격벽 관통관의 온도분포 응답성능을 분석하였다.

Fig. 4의 방화시험 시편 설계를 토대로 생성된 과도 열전달 수치 해석 모델은 Fig. 6 에 대표적으로 소켓 길이 $200 \mathrm{~mm}$ 에 대한 사양의 해석 모델을 도시하였다. 과도 열전달 수치해석에 사용된 유한요 소모델의 요소형태는 4 면체 솔리드 요소이며, $1,203,128$ 개의 유한 요소와 282,083 개의 절점으로 구성하였다.

과도 열전달 해석의 정확도를 높이기 위해 수치해석 모델의 각 파트별 열전도(Thermal conductivity)와 비열(Specific heat)은 기존의 연구문헌 결과를 참고하여 온도변화에 따른 특성치를 입력하였으며 Fig. 7에 나타내었다.

과도 열전달해석에 적용되는 화염온도의 조건은 Fig. 8에 나 타내었다.

Fig. 8의 좌측에 나타나 있는 것처럼, A60 격벽 관통관의 방 화성능시험에서는 화염노에 격벽 관통관이 부착된 시험편을 단 열재 도포면이 화염노 내부의 반대편에 놓이도록 수직방향으로 장착한 후, 화염 분사구(Flaming point)를 통해 가열된 화염노의 내부 온도를 Fig. 8의 우측에 나타나 있는 화염제어온도 곡선에 맞추어 조정하여 비화염노출면(Unexposed surface)의 격벽 관통 관 부재의 온도를 측정하고 규정온도의 만족 여부를 확인한다. Fig. 8의 우측에 제시된 화염제어온도 곡선은 다음의 식으로 표 현된다(MSC, 2010). 

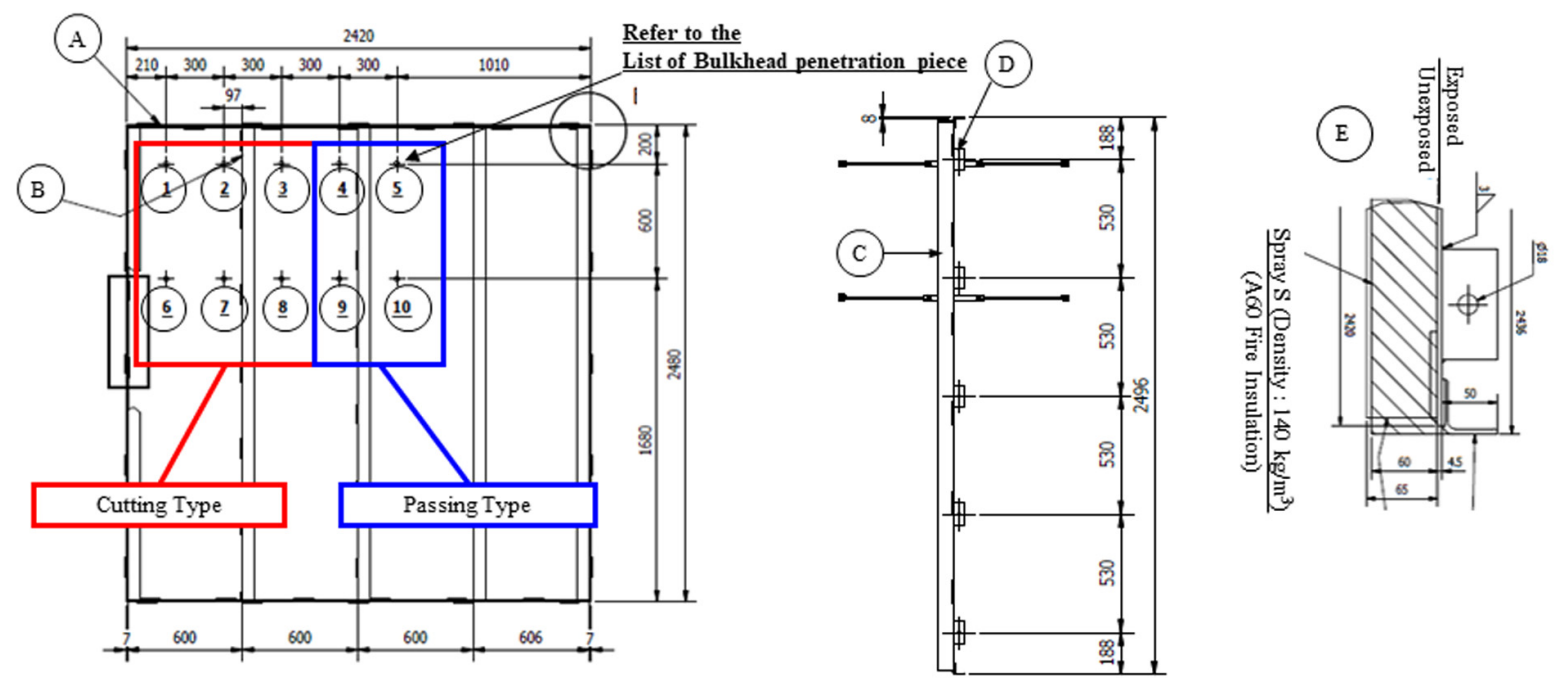

(a) fire test specimen design drawing

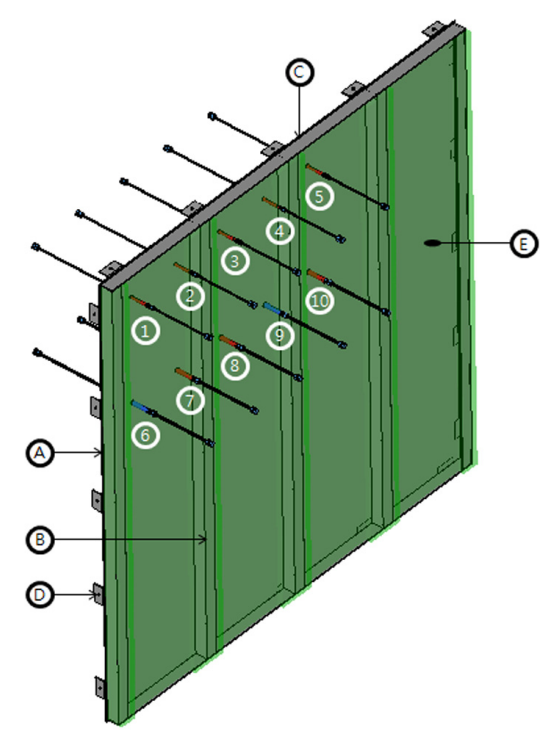

(b) 3-D concept model

Fig. 4 Fire test specimen design for A60 class bulkhead penetration piece

Table 1 Material type and main dimension of fire test specimen

\begin{tabular}{cccc}
\hline \hline No. & Part Name & Main Dimension & Material Type \\
\hline 1,4 & Penetration Piece & $\phi 18$ Socket $/(\phi 8$ Tube $)$ & SUS316L $/$ SUS316L \\
2 & Penetration Piece & $\phi 18$ Socket $/(\phi 8$ Tube $)$ & S45C $/$ Brass \\
3,5 & Penetration Piece & $\phi 18$ Socket $/(\phi 8$ Tube $)$ & S45C $/ \mathrm{S} 45 \mathrm{C}$ \\
6,9 & Penetration Piece & $\phi 25$ Socket $/(\phi 12$ Tube $)$ & SUS316L $/$ SUS316L \\
7 & Penetration Piece & $\phi 25$ Socket $/(\phi 12$ Tube $)$ & S45C $/$ Brass \\
8,10 & Penetration Piece & $\phi 25$ Socket $/(\phi 12$ Tube $)$ & S45C $/$ S45C \\
A & Bulkhead Plate & $2420 \times 2480 \times 4.5 \mathrm{t}$ & Mild Steel \\
B & Bulkhead Stiffener & $65 \times 65 \times 6 \mathrm{t}$ & Mild Steel \\
C & Sealing & $100 \times 4.5 \times 2420 \mathrm{~L}$ & Mild Steel \\
D & Mounting Plate & $80 \times 80 \times 4.5 \mathrm{t}$ & Mild Steel \\
E & A60 Fire Insulation & $60 \mathrm{t} / 90 \mathrm{t}$ & Spray S
\end{tabular}




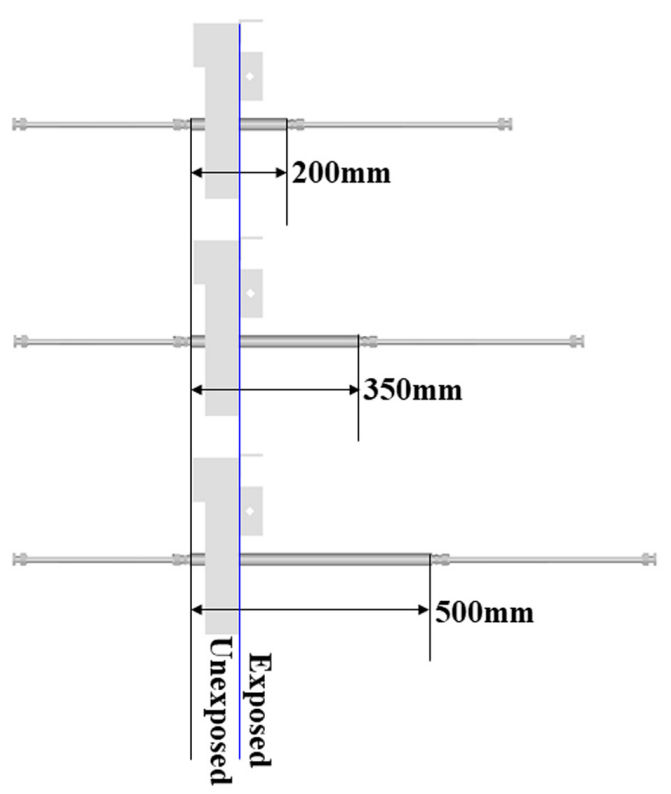

Fig. 5 Design parameter for socket length

Table 2 Design parameter matrix for transient heat transfer analysis

\begin{tabular}{|c|c|c|c|c|c|c|c|c|}
\hline Case No. & Tube size & Tube material & Socket size & Socket material & Piece type & \multicolumn{3}{|c|}{ Socket length $[\mathrm{mm}]$} \\
\hline Case 1 & $\phi 8$ & SUS316L & $\phi 18$ & SUS316L & Cutting type & 200 & 350 & 500 \\
\hline Case 2 & $\phi 8$ & Brass & $\phi 18$ & $\mathrm{~S} 45 \mathrm{C}$ & Cutting type & 200 & 350 & 500 \\
\hline Case 3 & $\phi 8$ & $\mathrm{~S} 45 \mathrm{C}$ & $\phi 18$ & $\mathrm{~S} 45 \mathrm{C}$ & Cutting type & 200 & 350 & 500 \\
\hline Case 4 & $\phi 8$ & SUS316L & $\phi 18$ & SUS316L & Passing type & 200 & 350 & 500 \\
\hline Case 5 & $\phi 8$ & $\mathrm{~S} 45 \mathrm{C}$ & $\phi 18$ & $\mathrm{~S} 45 \mathrm{C}$ & Passing type & 200 & 350 & 500 \\
\hline Case 6 & $\phi 12$ & SUS316L & $\phi 25$ & SUS316L & Cutting type & 200 & 350 & 500 \\
\hline Case 7 & $\phi 12$ & Brass & $\phi 25$ & $\mathrm{~S} 45 \mathrm{C}$ & Cutting type & 200 & 350 & 500 \\
\hline Case 8 & $\phi 12$ & $\mathrm{~S} 45 \mathrm{C}$ & $\phi 25$ & $\mathrm{~S} 45 \mathrm{C}$ & Cutting type & 200 & 350 & 500 \\
\hline Case 9 & $\phi 12$ & SUS316L & $\phi 25$ & SUS316L & Passing type & 200 & 350 & 500 \\
\hline Case 10 & $\phi 12$ & $\mathrm{~S} 45 \mathrm{C}$ & $\phi 25$ & $\mathrm{~S} 45 \mathrm{C}$ & Passing type & 200 & 350 & 500 \\
\hline
\end{tabular}

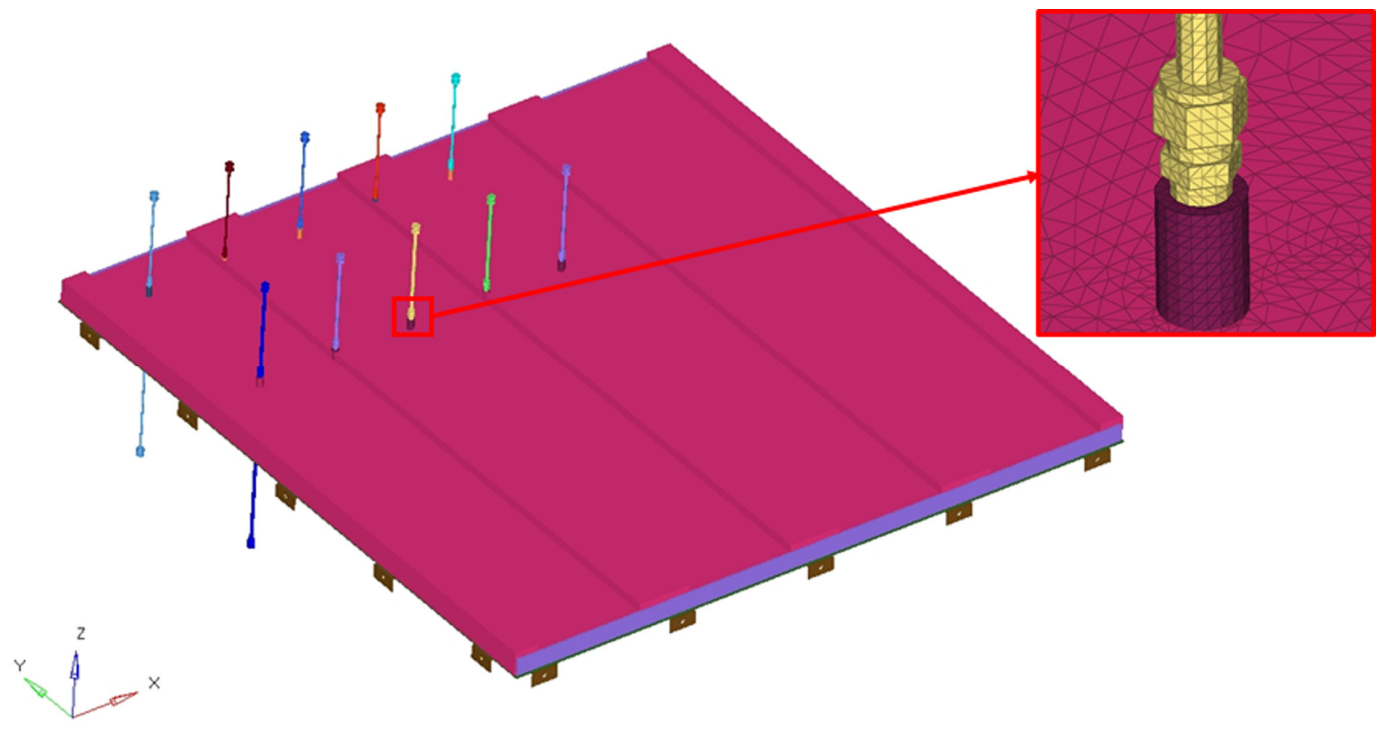

Fig. 6 Finite element model for socket length $200 \mathrm{~mm}$ 

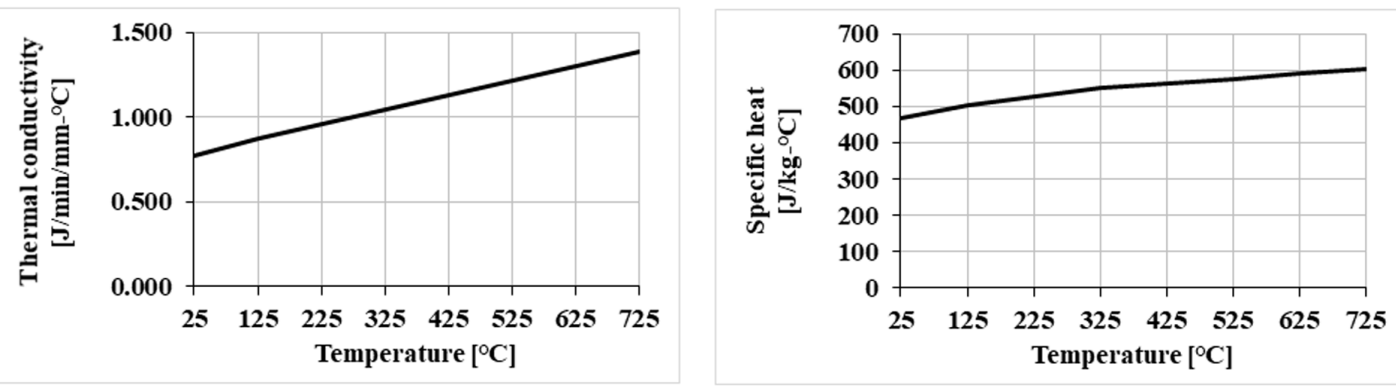

(a) SUS316L (Goodfellow, 1993)
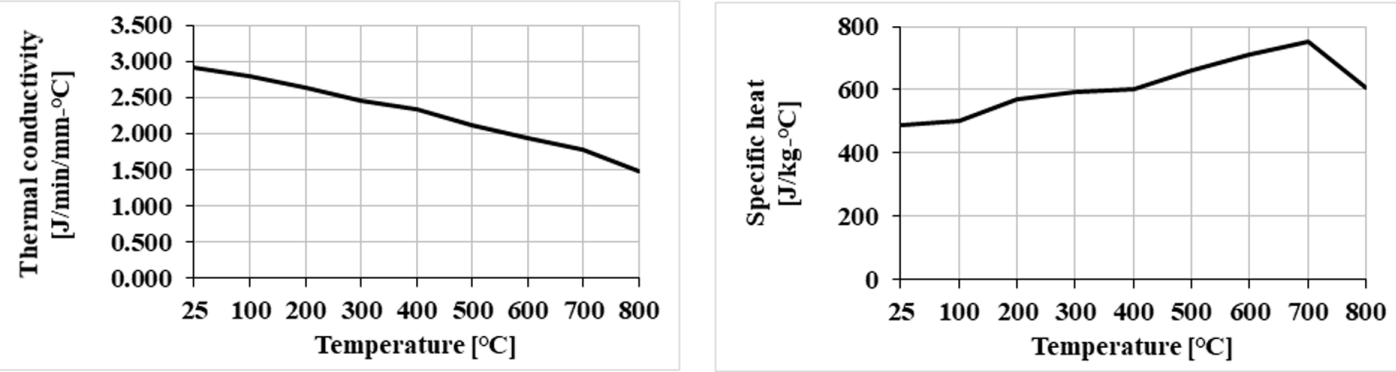

(b) S45C (Seo et al., 2012)
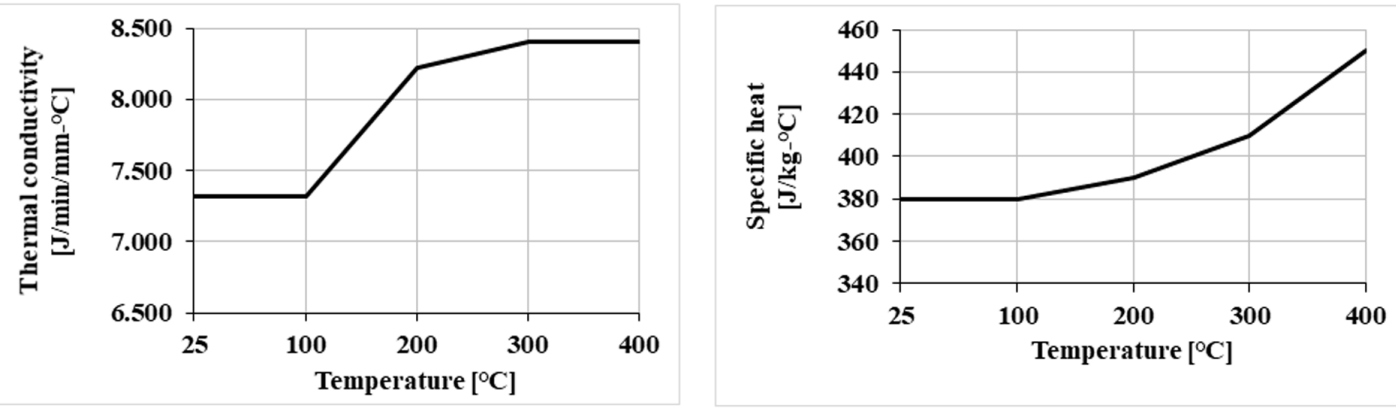

(c) Brass (Kothandaraman and Subramanyan, 2004)
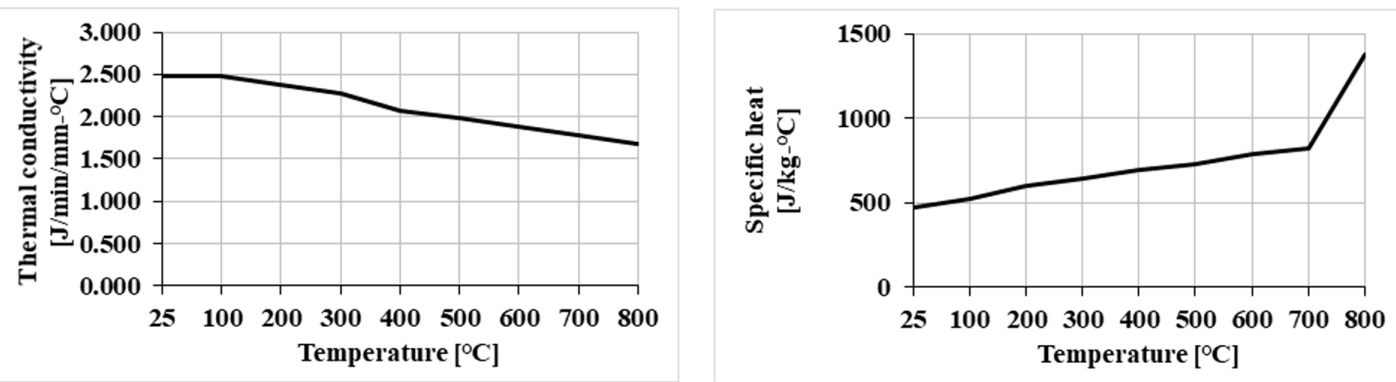

(d) Mild steel (Lee and Song, 2013)
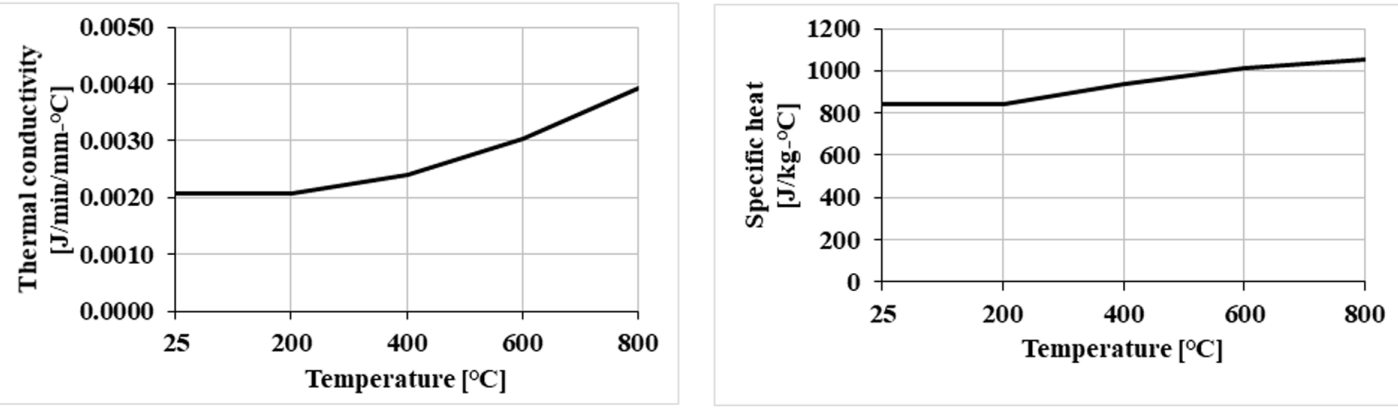

(e) Insulation (Promat, 2018)

Fig. 7 Thermal conductivity(left) and specific heat(right) for parts of bulkhead penetration piece 

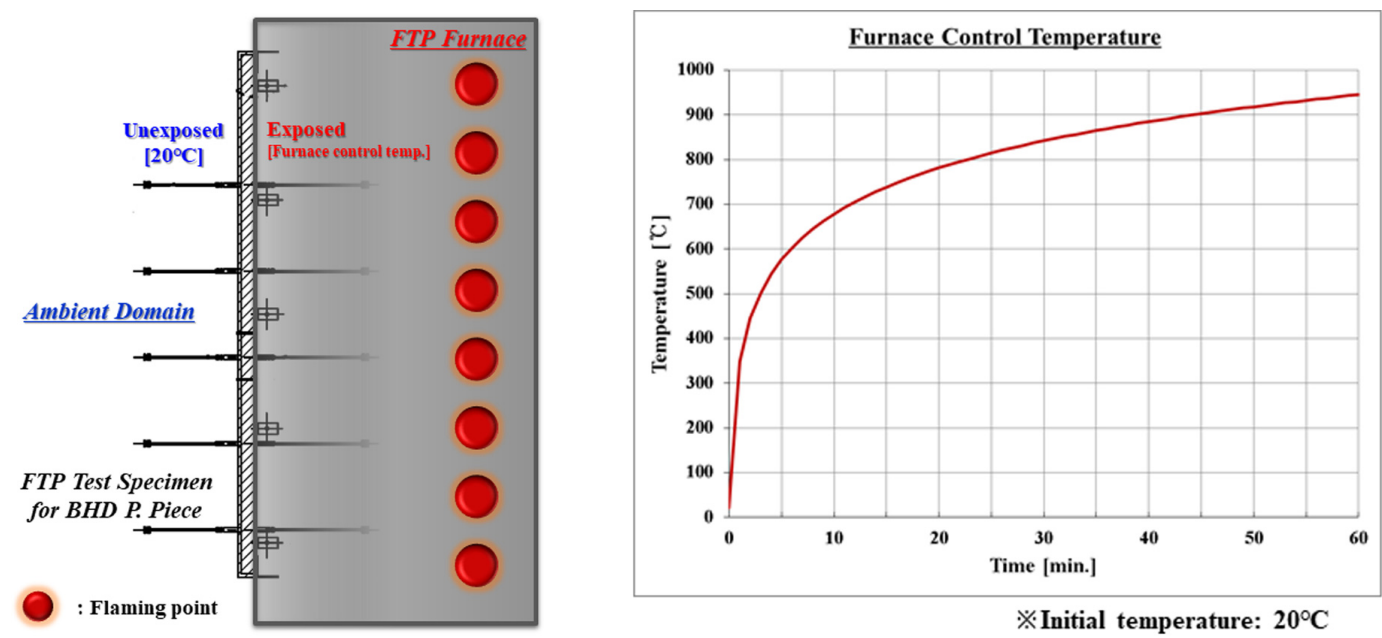

※Initial temperature: $20^{\circ} \mathrm{C}$

Fig. 8 Fire test condition (left) and furnace control temperature (right)

$$
T=340 \log _{10}(8 t+1)+20\left[{ }^{\circ} \mathrm{C}\right]
$$

여기서 $T$ 는 가열온도, $t$ 는 분단위의 시간을 나타낸다. 식 (4)에 따라 $\mathrm{A} 60$ 격벽 관통 관의 시험편은 60 분간 $940^{\circ} \mathrm{C}$ 까지 점진적으 로 가열된다.

\section{3 설계 파라미터 변동에 따른 과도 열전달 특성}

Table 2에 정리된 $\mathrm{A} 60$ 급 격벽 관통 관의 설계 파라미터 변동 행렬에 따라 범용 유한요소해석 프로그램인 MSC.NASTRAN의 열해석 솔버(MSC software, 2017)를 사용하여 과도 열전달해석 을 수행하였다. 과도 열전달해석 기반 $\mathrm{A} 60$ 급 격벽 관통 관의 방 화성능 평가를 위한 온도측정 위치는 MSC.307(88) 규정에 따라 Fig. 9와 Table 3에 나타낸 바와 같이 단열재 상부에 격벽 관통 관 조립체인 컨넥터(Connector)가 드러나는 경우 소켓에 2지점, 튜브에 2지점씩 총 4지점의 온도를 측정하며, 단열재 두께로 인 해 컨넥터가 드러나지 않는 경우 단열재에 인접된 튜브의 2지

\section{점 온도를 측정한다.}

과도 열전달해석을 통한 최종 60 분 가열 후의 온도계측 결과 는 각각의 온도측정 위치 별로 Table 3과 Fig. 10에 정리하여 나 타내었다. 규정만족 여부의 판독 편의성을 위해 Table 3 과 Fig. 10 의 온도계측 결과는 측정온도에서 상온 $20^{\circ} \mathrm{C}$ 를 차감한 편차 온도 기준으로 정리하였다.

Table 3과 Fig. 10에 나타난 바와 같이 MSC 화재시험 절차서 에서 규정된 편차온도인 $180^{\circ} \mathrm{C}$ 를 초과하는 $\mathrm{Case}$ 는 소켓길이가 $200 \mathrm{~mm}$ 와 $350 \mathrm{~mm}, 500 \mathrm{~mm}$ 의 경우에 대해 $3-1,3-2,5-1,5-2,7-3$, $7-4,8-1,8-2,10-1,10-2$ 측정위치에서 나타났다. 화재시험 절차 서의 규정상 측정위치 한곳 이상에서의 측정 편차온도가 $180^{\circ} \mathrm{C}$ 를 초과하면 그 시편 자체는 규정을 만족하지 못하는 것으로 간주하기 때문에 Table 3 에 나타난 것처럼 $200 \mathrm{~mm}, 350 \mathrm{~mm}$, $500 \mathrm{~mm}$ 의 모든 소켓 길이에서 Case 3 , Case 5, Case 7, Case 8, Case 10 의 일부 설계조합은 $\mathrm{A} 60$ 급 격벽 관통 관으로 적용되기 어려운 것으로 나타났다.
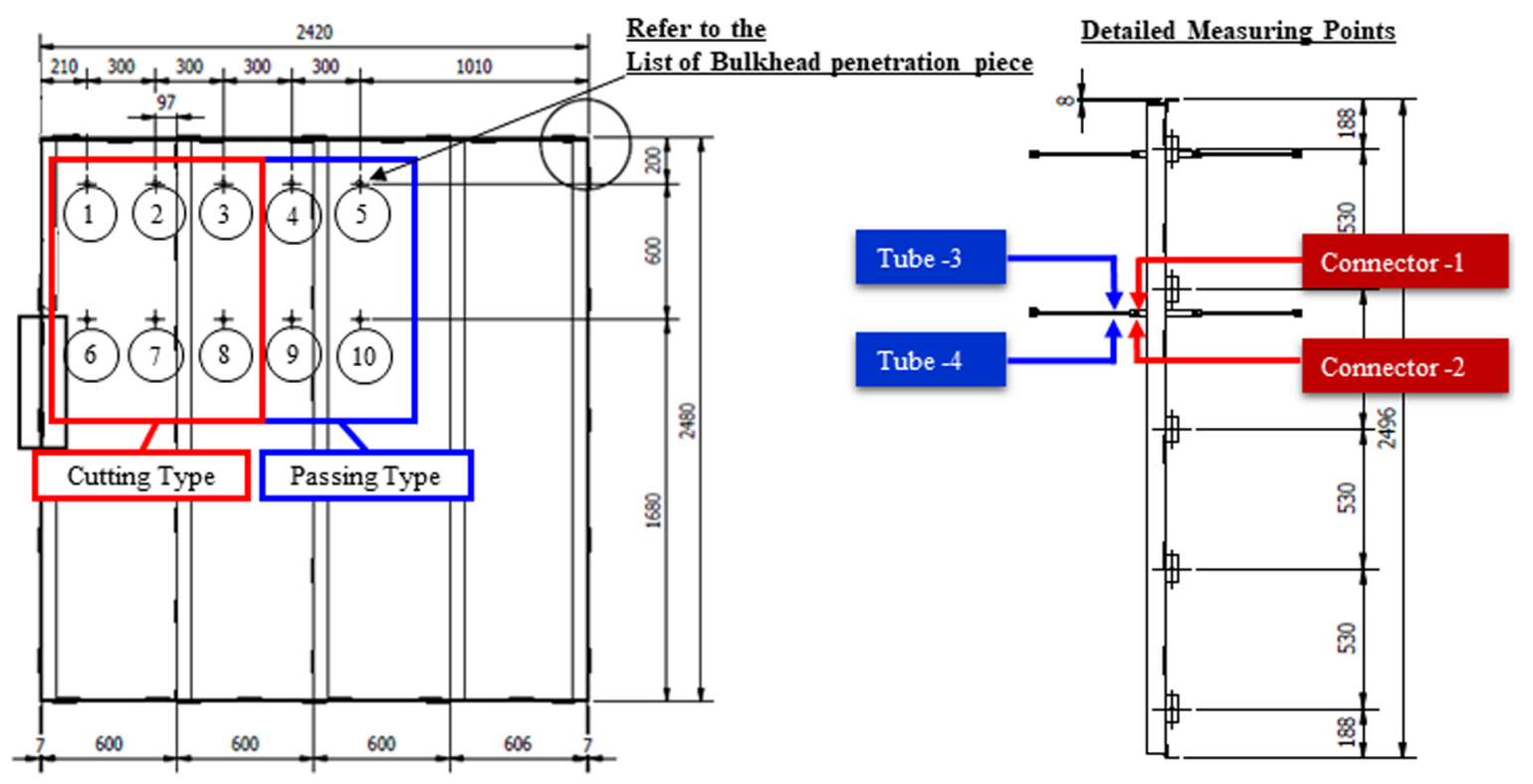

Fig. 9 Detailed temperature measuring points 
Table 3 Temperature measuring results from transient heat transfer analysis

\begin{tabular}{|c|c|c|c|c|c|}
\hline \multirow{2}{*}{ Case No. } & \multirow{2}{*}{ Measuring point No.- } & \multicolumn{3}{|c|}{ Temperature $\left[{ }^{\circ} \mathrm{C}\right]$} & \multirow{2}{*}{ Remark } \\
\hline & & Socket length : $200 \mathrm{~mm}$ & Socket length : $350 \mathrm{~mm}$ & Socket length : $500 \mathrm{~mm}$ & \\
\hline \multirow{4}{*}{ Case 1} & 1-1 (socket) & 144.5 & 143.5 & 143.3 & OK \\
\hline & $1-2$ (socket) & 144.4 & 143.4 & 143.3 & OK \\
\hline & $1-3$ (tube) & 31.9 & 31.8 & 31.8 & $\mathrm{OK}$ \\
\hline & $1-4$ (tube) & 32.0 & 31.9 & 31.9 & OK \\
\hline \multirow{4}{*}{ Case 2} & - & - & - & - & \\
\hline & - & - & - & - & \\
\hline & $2-3$ (tube) & 169.7 & 167.2 & 166.4 & OK \\
\hline & 2-4 (tube) & 169.7 & 167.2 & 166.4 & OK \\
\hline \multirow{4}{*}{ Case 3} & 3-1 (socket) & 210.2 & 209.4 & 208.9 & Fail \\
\hline & 3-2 (socket) & 210.2 & 209.4 & 208.9 & Fail \\
\hline & 3-3 (tube) & 84.5 & 84.2 & 84.0 & OK \\
\hline & 3-4 (tube) & 84.5 & 84.2 & 84.1 & $\mathrm{OK}$ \\
\hline \multirow{4}{*}{ Case 4} & - & - & - & - & \\
\hline & - & - & - & - & \\
\hline & 4-3 (tube) & 102.3 & 98.1 & 97.8 & OK \\
\hline & 4-4 (tube) & 102.3 & 98.1 & 97.8 & OK \\
\hline \multirow{4}{*}{ Case 5} & 5-1 (socket) & 213.9 & 208.0 & 204.8 & Fail \\
\hline & 5-2 (socket) & 213.8 & 208.0 & 204.8 & Fail \\
\hline & 5-3 (tube) & 81.2 & 79.3 & 78.3 & OK \\
\hline & 5-4 (tube) & 81.2 & 79.3 & 78.3 & OK \\
\hline \multirow{4}{*}{ Case 6} & 6-1 (socket) & 165.8 & 163.4 & 163.2 & OK \\
\hline & 6-2 (socket) & 165.8 & 163.5 & 163.2 & OK \\
\hline & 6-3 (tube) & 35.2 & 35.0 & 34.9 & OK \\
\hline & 6-4 (tube) & 35.1 & 34.8 & 34.8 & $\mathrm{OK}$ \\
\hline \multirow{4}{*}{ Case 7} & - & - & - & - & \\
\hline & - & - & - & - & \\
\hline & 7-3 (tube) & 186.4 & 181.9 & 180.3 & Fail \\
\hline & $7-4$ (tube) & 186.4 & 181.8 & 180.2 & Fail \\
\hline \multirow{4}{*}{ Case 8} & 8-1 (socket) & 230.9 & 228.6 & 227.5 & Fail \\
\hline & 8-2 (socket) & 231.0 & 228.6 & 227.5 & Fail \\
\hline & $8-3$ (tube) & 93.0 & 92.2 & 91.8 & OK \\
\hline & $8-4$ (tube) & 92.8 & 92.0 & 91.6 & $\mathrm{OK}$ \\
\hline \multirow{4}{*}{ Case 9} & - & - & - & - & \\
\hline & - & - & - & - & \\
\hline & $9-3$ (tube) & 108.7 & 104.5 & 104.2 & $\mathrm{OK}$ \\
\hline & 9-4 (tube) & 108.7 & 104.5 & 104.2 & OK \\
\hline \multirow{4}{*}{ Case 10} & 10-1 (socket) & 232.5 & 226.0 & 222.6 & Fail \\
\hline & $10-2$ (socket) & 232.5 & 226.0 & 222.6 & Fail \\
\hline & 10-3 (tube) & 87.7 & 85.5 & 84.5 & OK \\
\hline & 10-4 (tube) & 87.6 & 85.5 & 84.4 & OK \\
\hline
\end{tabular}

대표적으로 소켓길이 $200 \mathrm{~mm}$ 에 대해서 과도 열전달해석을 통 한 60 분 가열 후 시편의 온도분포 결과를 Fig. 11에 도시하였다.

Fig. 11에 나타난 바와 같이 비화염노출면에서의 최대 온도는 $263^{\circ} \mathrm{C}$ 로 나타났으며, 화염노출면에서는 $885^{\circ} \mathrm{C}$ 로 나타났다. Table 3 과 Fig. 10 11에서 나타난 바와 같이 소켓의 길이가 길어질수록 비화염노출면에서의 온도분포가 다소 낮아지지만 영향도가 높지 


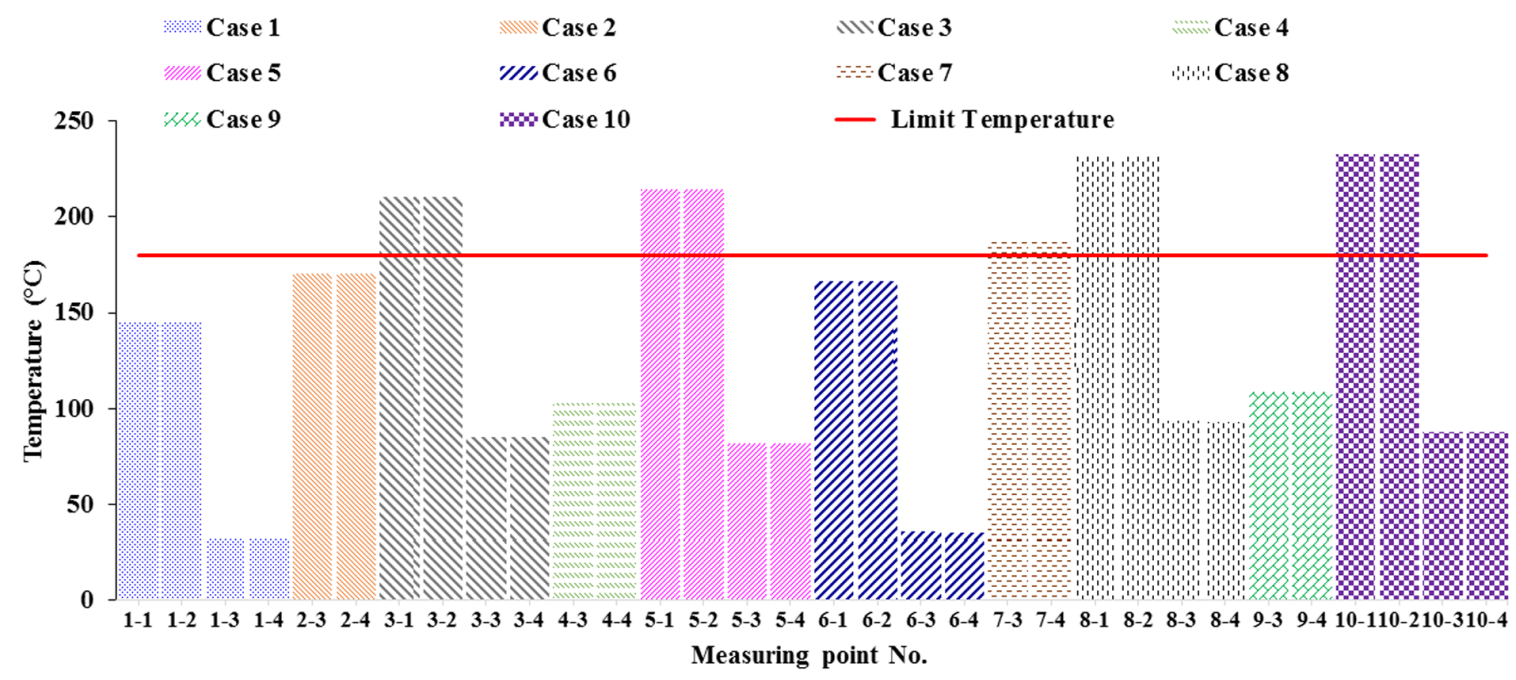

(a) Socket length : $200 \mathrm{~mm}$

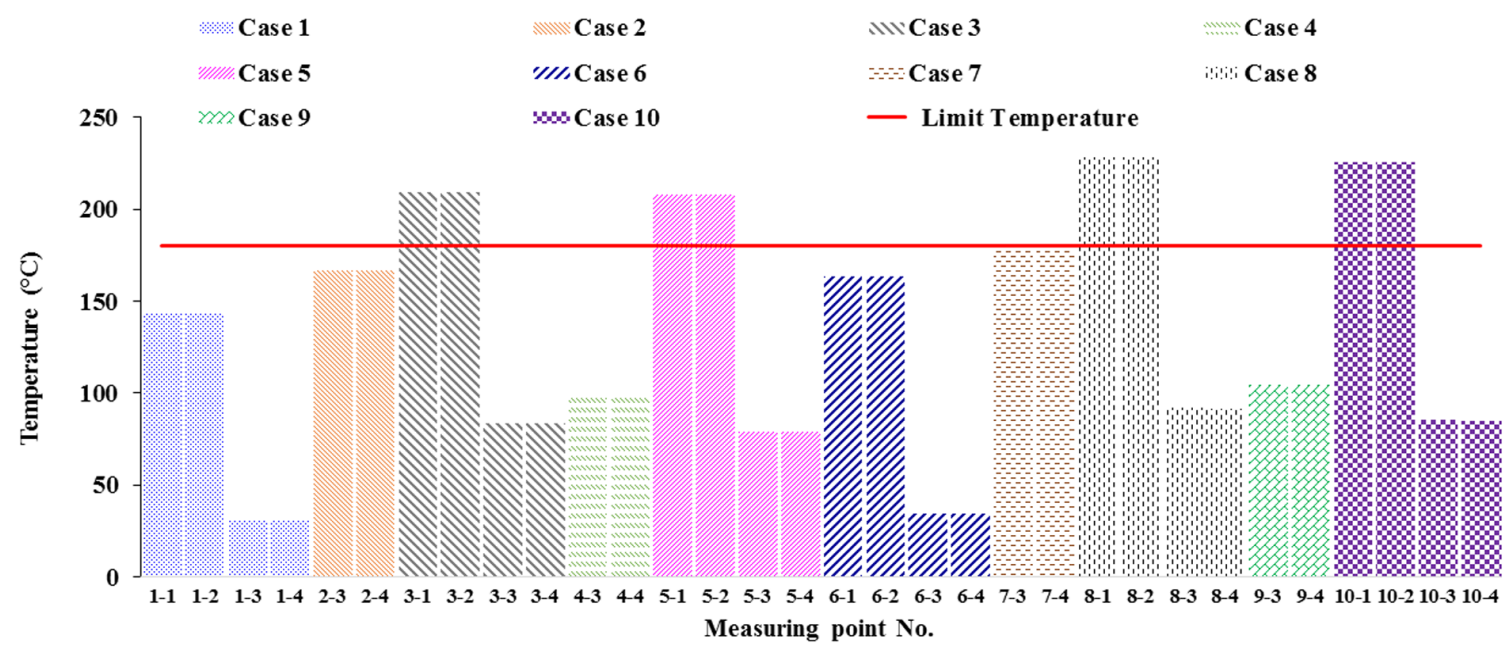

(b) Socket length : $350 \mathrm{~mm}$

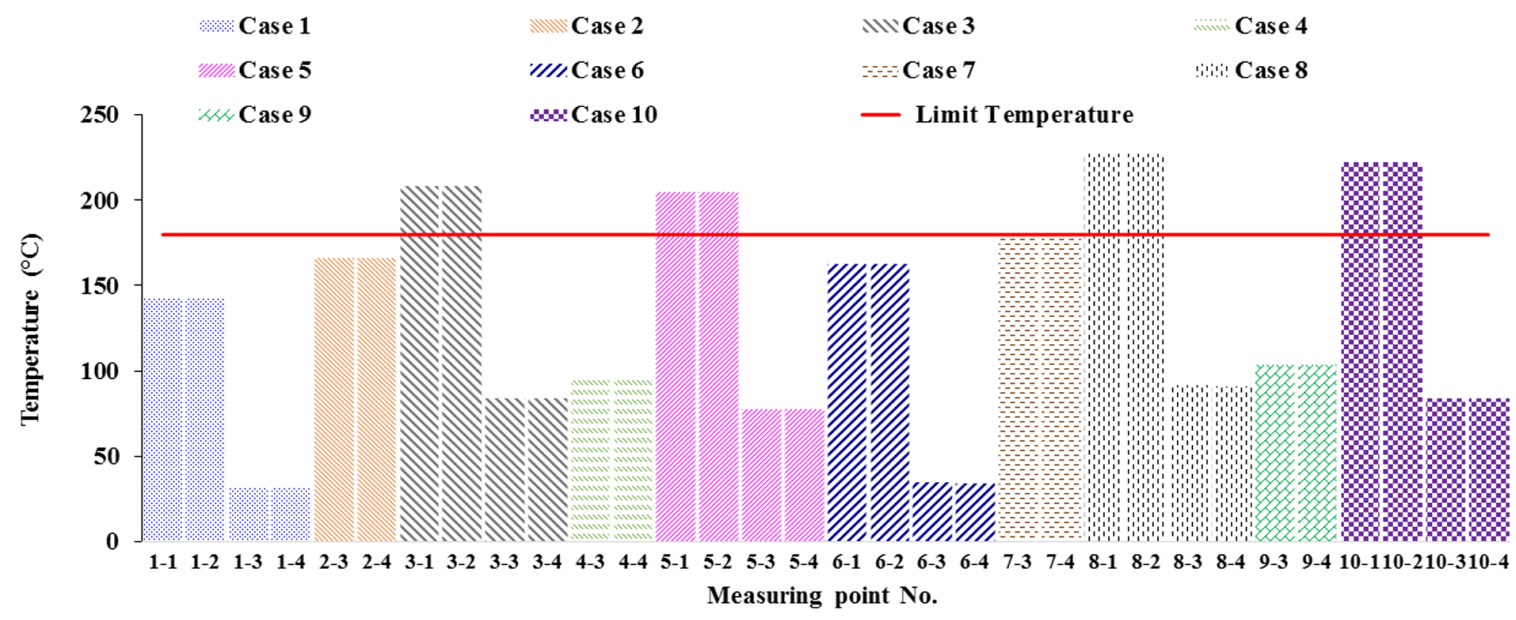

(c) Socket length : $500 \mathrm{~mm}$

Fig. 10 Design parameter effects on temperature measuring results

않은 것으로 나타났고, 반면에 재질, 직경 및 관 형태의 설계조합 이 방화성능에 영향도가 높은 것으로 나타났다.

제작비용의 Case 별 영향도는 관통 관의 재질과 형상을 기준
으로 산정되었고, 건조 생산성과 관련해서는 Table 4 와 같은 항 목에 대한 실제 조선소 의장생산 작업자의 정성적인 평가를 기 준으로 산정하였다. 생산성 영향도 평가에서 재질과 직경, 길이 


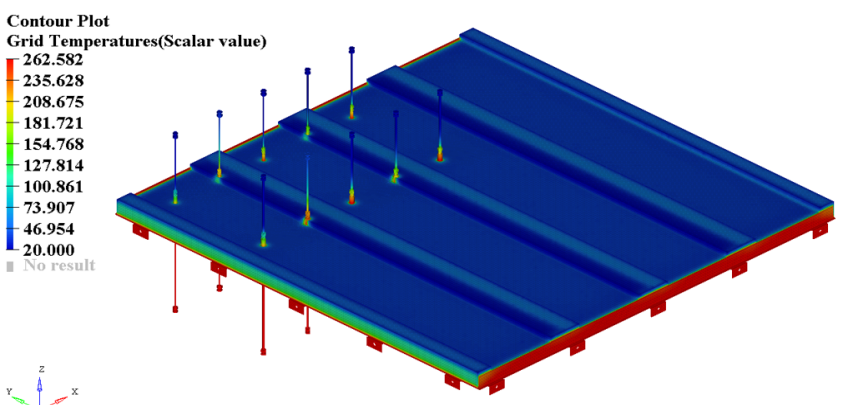

(a) Socket length $200 \mathrm{~mm}$ : Unexposed face

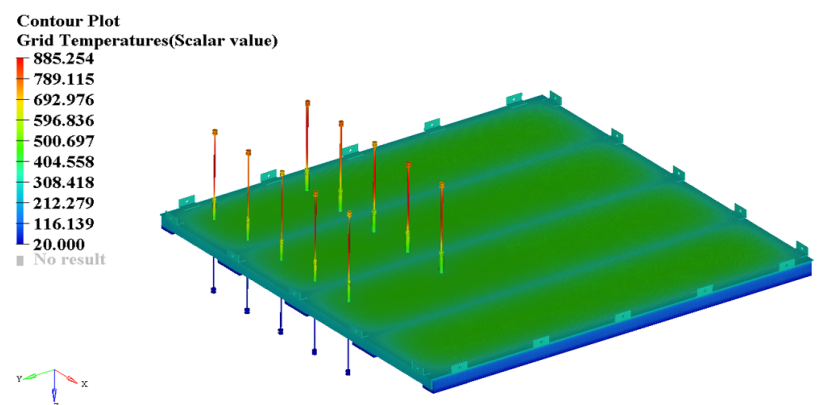

(b) Socket length $200 \mathrm{~mm}$ : Exposed face

Fig. 11 Temperature distribution contour results

Table 4 Productivity rating for bulkhead penetration piece

\begin{tabular}{cccccc}
\hline & \multicolumn{3}{c}{ Grade } \\
Item & Very bad & Bad & Normal & Good & Very good \\
\cline { 2 - 5 } & 1 & $\cdots$ & 10 \\
\hline
\end{tabular}

\section{Work requirement time}

Damage frequency during work process

Work convenience

Maintenance between work process $\mathrm{A} / \mathrm{S}$ frequency

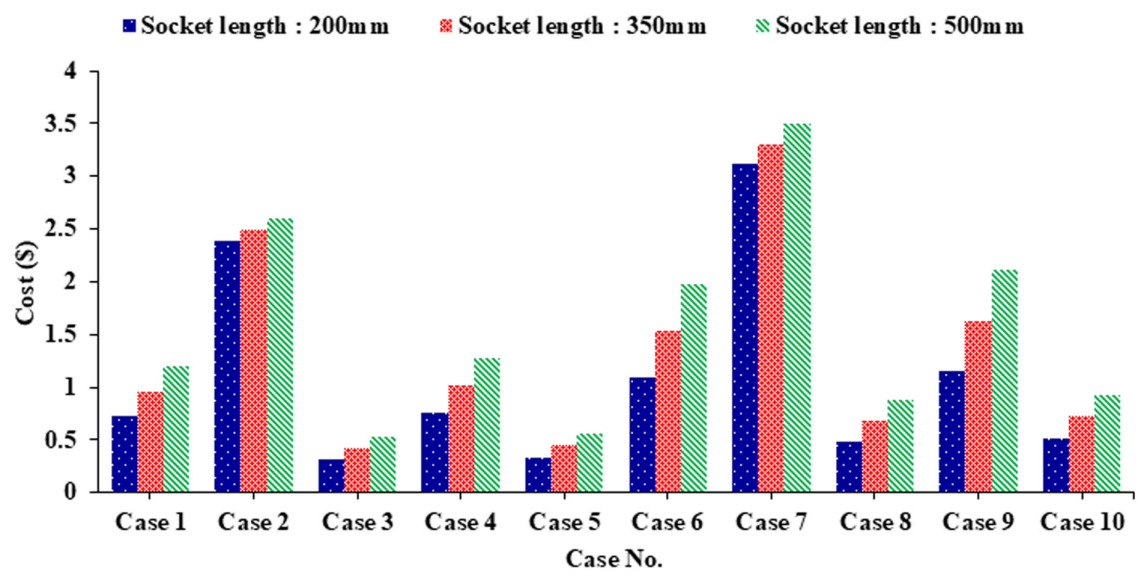

(a) Cost effect

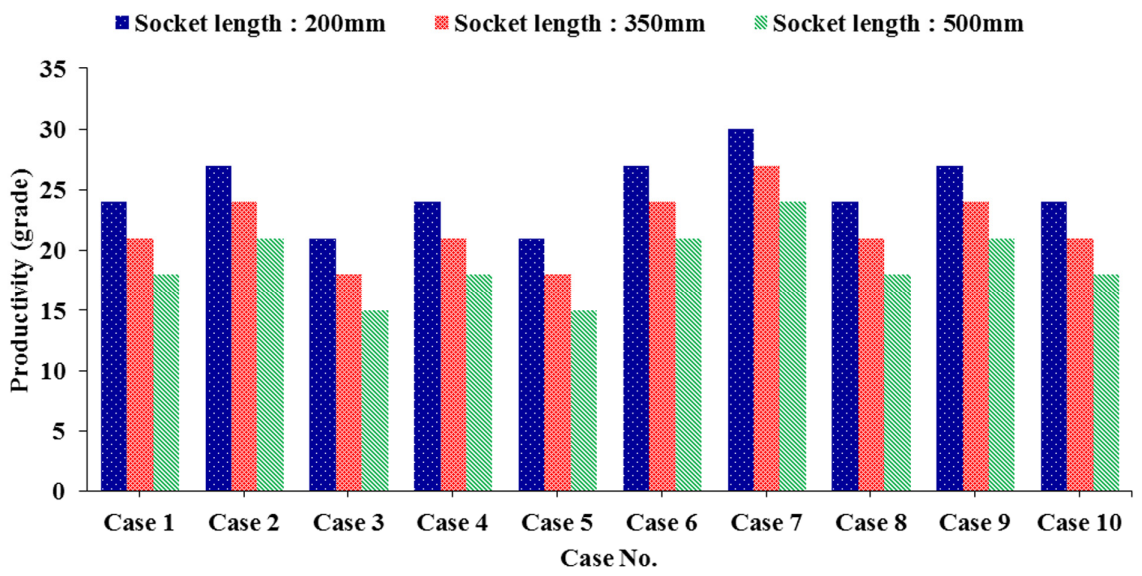

(b) Productivity effect

Fig. 12 Design parameter effects on cost and productivity 
에 따른 작업 편리성이 정성적으로 $30 \%$ 정도의 가감이 있는 것 으로 직접 면담을 통해 확인 되었고, 설계 파라미터 조합 상에 생산성이 가장 높은 경우 10 점, 그 이후 $30 \%$ 씩 감하여 생산성 점수를 책정하고 이를 합산하여 Fig. 12 (b)에 도식적으로 나타 내었다.

제작비용 및 건조 생산성에 대한 각 Case 별 영향도 분석 결 과는 Fig. 12에 도시하였다.

Fig. 12 (a)에 나타난 바와 같이, Case 7인 경우 제작비용 상승 률이 가장 큰 반면, Case 3 인 경우 제작비용이 가장 낮은 것으 로 나타났다. 즉, 황동재질의 소재를 사용할 경우 제작비용이 높아지고, $\mathrm{S} 45 \mathrm{C}$ 재질을 적용할 경우 제작비용을 낮출 수 있으 며, 길이와 직경의 증가는 제작비용의 비례적인 증가를 나타낸 다. 또한 SUS316L 재질을 적용할 경우 중간 정도의 제작비용이 소요됨을 알 수 있다. Fig. 12 (b)에 나타난 것처럼 강성이 상대 적으로 낮은 소재인 황동재질을 적용하고 직경이 크고 길이가 짧은 경우 생산성이 향상되는 것으로 나타났으며, 강성이 상대 적으로 높은 소재인 $\mathrm{S} 45 \mathrm{C}$ 재질을 적용하고 직경이 작고 길이가 긴 경우 생산성이 저하되는 것을 확인하였다. $\mathrm{A} 60$ 급 격벽 관통 관의 합리적인 설계 파라미터를 결정하기 위해 MSC.307(88) 방 화성능의 온도 규정, 제작비용 및 건조 생산성을 종합적으로 고 려할 경우, SUS316L 재질과 $200 \mathrm{~mm}$ 의 소켓 길이를 적용하는 것 이 적절한 것으로 분석되었다.

\section{4. 결 론}

본 연구에서는 $\mathrm{A} 60$ 급 구획에 적용되며 격벽을 관통하는 관의 열전달 특성을 검토하기 위해 유한요소법을 기반으로 과도 열전 달 수치해석을 수행하였다. 관의 재질, 직경 및 길이 치수를 주요 파라미터로 설정 하였으며 A60급 방화성능의 온도 규정, 제작비 용 및 건조 생산성을 주요 성능 응답치로 고려하여 합리적인 A60 급 격벽 관통 관의 설계 파라미터 조합을 과도 열전달해석을 통 해 검토하였다. 설계 파라미터 검토 결과로부터 소켓의 길이가 길어질수록 비화염노출면에서의 온도분포가 다소 낮아지지만 영 향도가 높지 않은 것으로 나타났고, 반면에 재질, 직경 및 관 형 상의 설계조합이 방화성능에 영향도가 높은 것으로 나타났다. 제 작비용과 관련하여 황동재질의 소재를 사용할 경우 제작비용이 높아지고, S45C 재질을 적용할 경우 제작비용을 낮출 수 있으며, 길이와 직경의 증가는 제작비용의 비례적인 증가를 나타내었고, $\mathrm{SUS} 316 \mathrm{~L}$ 재질을 적용할 경우 중간 정도의 제작비용이 소요됨을 확인 하였다. 생산성 측면에서는 강성이 상대적으로 낮은 소재인 황동재질을 적용하고 직경이 크고 길이가 짧은 경우 생산성이 향 상되는 것으로 나타났으며, 강성이 상대적으로 높은 소재인 $\mathrm{S} 45 \mathrm{C}$ 재질을 적용하고 직경이 작고 길이가 긴 경우 생산성이 저 하되는 것을 확인하였다. MSC.307(88) 방화성능의 온도규정 만 족여부와 관련하여 $\mathrm{S} 45 \mathrm{C}$ 재질의 경우 직경, 길이에 관계없이 온 도규정을 만족하지 못하였으며 재질이 황동일 때 튜브의 직경이 $\phi 12$ 인 경우 길이에 관계없이 온도규정을 만족하지 못하였다. 반 면 재질이 SUS316L인 경우 직경, 길이에 관계없이 모두 온도규 정을 만족하였다. $\mathrm{A} 60$ 급 격벽 관통 관의 합리적인 설계 파라미터 를 결정하기 위해 MSC.307 (88) 방화성능의 온도 규정, 제작비용
및 건조 생산성을 종합적으로 고려할 경우, SUS316L 재질과 $200 \mathrm{~mm}$ 의 소켓 길이를 적용하는 것이 가장 적절한 설계안으로 검토되었다. 본 연구에서 수행된 과도 열전달 수치해석 기반의 설계 사양 결정에 대한 검증은 추후 $\mathrm{A} 60$ 급 격벽 관통 관의 방화 성능 시험 연구논문에서 다루어질 예정이다.

$$
\text { 후 기 }
$$

본 연구는 산업통상자원부 대불산학융합지구조성사업과 중소 벤처기업부 지정 지역혁신센터사업(RIC) 중화학설비안전진단센 터(B0010843)의 지원을 받아 수행되었으며 연구비 지원에 감사 드립니다.

\section{References}

ABS, 2018. Mobile Offshore Drilling Units - Part 5 Fire and Safety. Rules for Building and Classing, USA.

Barletta, A., Lazzari, S., Zanchini, E., Terenzi, A., 2008. Transient Heat Transfer from an Offshore Buried Pipeline during Start-up Working Conditions. Heat Transfer Engineering, 29(11), 942-949.

Goodfellow, 1993. Metals, Alloys, Compounds, Ceramics, Polymers, Composites Catalogue 1993/94. GoodfellowMetals Ltd., Cambridge.

Huh, C., Kang, S.G., Hong, S., Choi, J.S., Baek, J.H., 2008. Thermal-Hydraulic Analysis of Pipeline Transport System for Marine Geological Storage of Carbon Dioxide. Journal of Ocean Engineering and Technology, 22(6), 88-94.

IMO, 2010. International Convention for the Safety of Life at Sea. SOLAS 1999/2000 Amendment, UK.

Kang, G.I., Kwak, S.Y., Park, C.S., 2017. Design and Evaluation of the Thermal Capability to Secure a Working Time of Cryogenic Explosion-proof Camera in LNG Carrier Tank. International Journal of Naval Architecture and Ocean Engineering, 9, 568-576.

Kothandaraman, C.P., Subramanyan, S., 2004. Heat and Mass Transfer Data Book. $5^{\text {th }}$ Edition, New Age International (P) Ltd., India.

Lee, J., Song, C.Y., 2013. Estimation of Submerged-arc Welding Design Parameters using Taguchi Method and Fuzzy Logic. Journal of Engineering Manufacture, 227(4), 532-542.

Lee, J.C., Seo, Y.K., Lee, C.J., 2012. A Study on the Anti-icing Performance Evaluating and Design Guide by Heating Coil for Upper Deck of Icebreaking Vessels. Journal of the Society of Naval Architects of Korea, 49(6), 541-549.

Moon, J.G., Park, J.C., Kwon, Y.H., Yoo W.S., Ahn, S.W., 2010. Study of Heat Transfer and Safety Evaluation for Heating Coils in the Fuel Tank of a Ship. Journal of Ocean Engineering and Technology, 24(5), 22-30.

MSC(Maritime Safety Committee), 2010. Adoption of the 
International Code for Application of Fire Test Procedures. MSC.307(88), UK.

MSC software, 2017. MSC.NASTRAN User's Manual. MSC software, USA.

Murawski, L., 2018. Thermal Interaction Between Main Engine Body and Ship Hull. Ocean Engineering, 147, 107-120.

Oh, J.S., Lee, I.S., Yoon, H.K., Sung, H.K., 2017. Thermal and Structural Analyses of Semi-metallic Gasket Joined with Graphite Seal for Ship Engine Piping Flange. Journal of Ocean engineering and Technlogy, 31(5), 352-356.

Promat, 2018. Thermal Characteristics. [Online] Available at :
$<$ http://www.promat-marine.com/en/products/promaguard $>$ [Accessed 04 April. 2018].

Soe, Y.H., Tanabe, I., Iyama, T., Da Cruz, J.R., 2012. Estimation Tool for Optimum Cutting Condition of Difficult to Cut Materials. Journal of Machine Engineering, 12(1), 76-88.

Yunus, A.C., Afshin, J.G., 2012. Heat and Mass Transfer: Fundamentals and Applications. $4^{\text {th }}$ Edition, McGraw-Hill Education Korea, Korea.

Zhou, B., Han, X,. Guo, W., Liu, Y., Tan, S.K., 2017. Numerical and Experimental Study on Cutting Access Opening in Ship Structure. Journal of Ship Production and Design, 33(1), 12-23. 